\title{
密封小線源の簡単な線量計算
}

九州大学医学部附属病院放射線部

高、田卓雄

（受理．炤和52年 5 月26日）

(Code No. 41110, 41250)

\section{A SIMPLE DETERMINATION OF THE DOSE-RATE AT POINT IN WATER AROUND IINEAR RADIOACTIVE SOURSE}

(Received: May 6, 1977)

\author{
By TAKAO TAKADA
}

Department of Radiology, Kyusyu University Hospipital, Fukuoka.

\section{Summary}

This paper describes the simple formula giving the dose rate in water around linear radioactive source. The formula was based on modified Sivert's formula. The calculated value was compared with several author's datas or experimental value, the results were as follows:

1) the maximum error between the calculated dose rate for ${ }^{226} \mathrm{Ra}$ source and Uchiyama's date was less than 10 percent.

2) agreement between calculated and measured attenuation curves with distance from $R$ a source was seen to be similar in shape.

3) agreement between the calculated dose distribution around ${ }^{137} \mathrm{Cs}$ source and Klvenhagen's data was seen to be similar.

\section{1.はじめに}

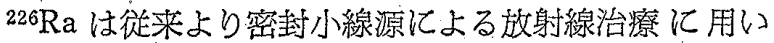
られてきたが，最近では ${ }^{60} \mathrm{Co} や{ }^{137} \mathrm{Cs}$ 線源も用いられ るようになってきた，しかしとれ等の小線源（針，管） を放射線治寮汇用いる場合，ラジウム等量というととで 使用されることが多く，しかもラジウム線源での線量計 算屯空気中での計算值が使用されているというのが現状 である. そこでてれ等の線源を使用する場合の簡単な水 中に扔ける吸収線量の計算方法を榆討し，従来のあの之
比較を行なったので報告する。

\section{2. 方}

法

Fig. 1 亿示す点P.に拈ける線量計算の方法はいるいる あるが，点Pが空気中にある場合の最す簡単な方法は， Sivert の積分柿による方法であろう。しかしての方法で は組織に対する吸收，散乱の影響们方考慮されておらず， とれ等の補正汃必要となる。

ラジウム小線源では H. F. Batho2), 尾内99等, セシウ ム小線源では Kaven E. ${ }^{8}$; Horsler ${ }^{33}$ ，田崎10)等の検討し 


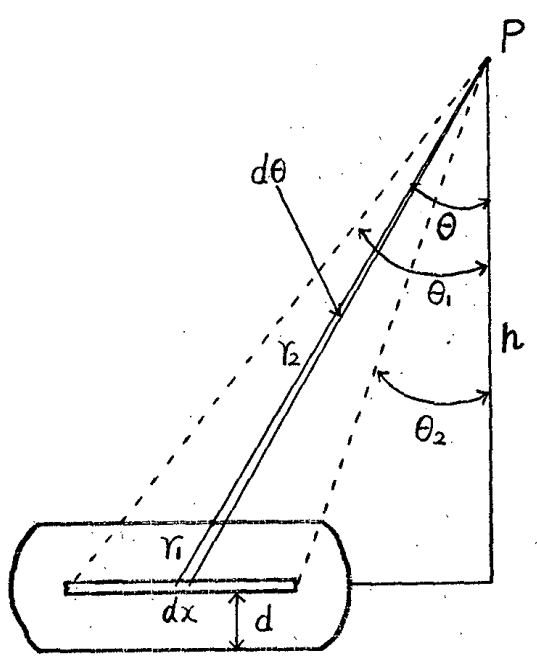

Fig. 1 Diagram illustrating how the exposure may be calculated at point near a linear source.

た方法もあるが，K.I. Ponnunni Kartha 等が点線源を 用いて検討した $A B$ factor を用いると下式に示すどとく 水中での点 $\mathrm{P} の$ 線量を ${ }^{137} \mathrm{Cs},{ }^{60} \mathrm{Co},{ }^{226} \mathrm{Ra}$ 等について比較 的簡単に求めることができる.

$d x$ 亿対応する空気中での線量 $d I_{\text {air }}$ とすれば，

$$
d I_{\mathrm{air}}=\Gamma \cdot \rho \cdot d x \cdot \frac{1}{\left(r_{1}+r_{2}\right)^{2}} \cdot e^{-u_{1} r_{1}}
$$

ただし

$\Gamma:$ specific gammaray constant

$\rho:$ linear density

$u_{1}:$ シールド物質の線吸収係数

$r_{1}$ : シールド物質を通過する距離

とする.

炊に水中での点Pにおける線量を求めるため，Kartha 等が検討した $\mathrm{AB}$ factor を用いると，

$$
d I_{\text {water }}=A B \cdot d I_{\text {air }}
$$

ただし，A: $e^{-u_{2} r_{2}}$ (absorption factor)

$\mathrm{B}:$ ビルドアップファクタ

$u_{2}$ : 水の線吸収係数

$r_{2}$ ：シールド物質表面から点 $\mathrm{P}$ までの距離

(1)式定(2)式に代大すると，

$$
d I_{\text {water }}=A B \cdot \Gamma \cdot \rho \cdot d x \cdot \frac{1}{\left(r_{1}+r_{2}\right)^{2}} \cdot e^{-u_{1} r_{1}}
$$

Kartha 等の点線源を用いた実験による亡，

$$
A B=\exp \left\{\left[\left(0.73 / E^{0.05}\right)-1\right] u_{2} r\right\}
$$

を用いると， ${ }^{60} \mathrm{Co},{ }^{137} \mathrm{Cs},{ }^{226} \mathrm{Ra}$ 線源について水中での線 量測定值と計算值がよく一致している，そこで(4)式を(3) 式に代入する.

$$
\begin{aligned}
d I_{\text {water }} & =\exp \left\{\left[\left(0.73 / E^{0.05}\right)-1\right] u_{2} h_{2}\right\} \\
& \times \Gamma \cdot \rho \cdot d x \cdot \exp \left(-u_{1} r_{1}\right)
\end{aligned}
$$

Fig. 1 より,

$$
r_{1}=d \operatorname{sce} \theta, \quad r_{2}=(h-d) \sec \theta
$$

であるので(5)式に代入する。

$$
\begin{aligned}
d I_{\text {water }} & =\Gamma \rho d x \cdot \frac{1}{\left(r_{1}+r_{2}\right)^{2}} \\
& \times \exp \left[\left(-u_{1} d+\left\{\left[\left(0.73 / E^{0.05}\right)-1\right](h-d) u_{2}\right) \sec \theta\right]\right.
\end{aligned}
$$

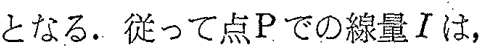

$$
\begin{aligned}
I & =\int d I_{\text {water }} \\
& =\frac{\Gamma \rho}{h} \int_{\theta_{2}}^{\theta_{1}} \exp \left(-u_{1} d+\left\{\left[\left(0.73 / E^{0.05}\right)-1\right](h-d) u_{2}\right\}\right) \\
& \times \sec \theta \cdot d \theta
\end{aligned}
$$

上式において $z=\sec \theta$ とおくとそのまま sievert の積 分が使用できる. つまりudの代わりに

$$
-u_{1} d+\left\{\left[\left(0.73 / E^{0.05}\right)-1\right](h-d) u_{2}\right\}
$$

を用い怔よりとととなる。

$$
-t=-u d_{1}+\left\{\left[\left(0.73 / E^{0.05}\right)-1\right](h-d) u_{2}\right\}
$$

とおくと,

$$
\int_{0}^{\theta} e^{-t \sec \theta} \cdot d \theta=E(\theta)
$$

$$
\begin{aligned}
E(\theta) & =\sec ^{-1} z-t \cdot I_{0}+\frac{t^{2}}{2 !} I_{1}-\frac{t^{3}}{3 !} I_{2} \\
& +\cdots \cdots \cdots \cdots(-1) n \frac{t^{n}}{n !} I_{n-1}
\end{aligned}
$$

そこだ,

$$
\begin{aligned}
& I_{0}=\ln \left\{z+\left(z^{2}-1\right)^{1 / 2}\right\} \\
& I_{1}=\left(z^{2}-1\right)^{1 / 2} \\
& \vdots \\
& I_{n}=\frac{1}{n}\left\{z^{n-1}\left(z^{2}-1\right)^{1 / 2}+(n-1) I_{n-2}\right\}
\end{aligned}
$$

從って,

$$
I=\left(E\left(\theta_{1}\right)-E\left(\theta_{2}\right) \frac{\Gamma \cdot \rho}{h}\right.
$$

として求めることができる。

\section{3. 結果およびその比較}

\section{1 線量計算値の比較}

Table 1 は Quimby のデータおよび内山等の計算結 果之(6)式で求めた值（ $\left(10 \mathrm{mCi}{ }^{226} \mathrm{R}\right.$, Filtration $=1.0 \mathrm{~mm}$ Active Length $=1.5 \mathrm{~cm}$ ) とを比較したあのである，䛊 差は10\%以下であるが，線源との距離が大きくなるにつ れて愦差が大きくなる㖽问となった。

\section{2 穾測値との比較}

Fig. 2 はラジウム針 $3 \mathrm{mCi}$ を水中で 5 分間照射し，線 
Table 1 A comparision of dose rate calculation for $10 \mathrm{mg}$ radium source by various investigators.

\begin{tabular}{|c|c|c|c|c|c|c|c|c|}
\hline \multirow{2}{*}{$\begin{array}{l}\text { Distance from } \\
\text { the source }\end{array}$} & \multirow{2}{*}{ Quimby } & \multicolumn{6}{|c|}{ Uchiyama } & \multirow{2}{*}{ Takada } \\
\hline & & $\mathrm{O}-\mathrm{ON}$ & $\mathrm{O}-\mathrm{AD}$ & $\mathrm{O}-\mathrm{BA}$ & $\mathrm{H}-\mathrm{ON}$ & $\mathrm{H}-\mathrm{AD}$ & $\mathrm{H}-\mathrm{BA}$ & \\
\hline $0.50(\mathrm{~cm})$ & 182.7 & 185.5 & 180.4 & 181.8 & 187.1 & 185.3 & 186.7 & 191.0 \\
\hline 0.75 & 98.5 & 100.1 & 100.1 & 98.4 & 99.4 & 102.6 & 101.2 & 102.0 \\
\hline 1.00 & 61.3 & 61.8 & 60.7 & 61.5 & 63.7 & 62.5 & 63.3 & 62.6 \\
\hline 1.50 & $\quad 29.8$ & 29.8 & 29.0 & 29.5 & 30.8 & 29.9 & 30.4 & 30.3 \\
\hline 2.00 & 17.3 & 17.3 & 16.7 & 17.0 & 17.9 & 17.2 & 17.6 & 17.8 \\
\hline-2.50 & 11.2 & 11.3 & 10.8 & 11.0 & 11.6 & 11.1 & 11.3 & 10.7 \\
\hline 3.00 & 7.8 & 7.9 & 7.8 & 7.6 & 8.1 & 7.7 & 7.9 & $7: 5$ \\
\hline 3.50 & 5.8 & 5.8 & 5.5 & 5.6 & 6.0 & 5.6 & 5.8 & 5.5 \\
\hline 4.00 & 4.5 & 4.5 & 4.2 & 4.2 & 4.6 . & 4.3 & 4.4 & 4.2 \\
\hline 4.50 & 3.5 & 3.5. & 3.3 & 3.3 & 3.6 & 3.4 & 3.4 & 3.3 \\
\hline 5.00 & 2.9 & 2.9 & 2.6 & 2.7 & 2.9 & 2.7 & 2.7 & 2.6 \\
\hline
\end{tabular}

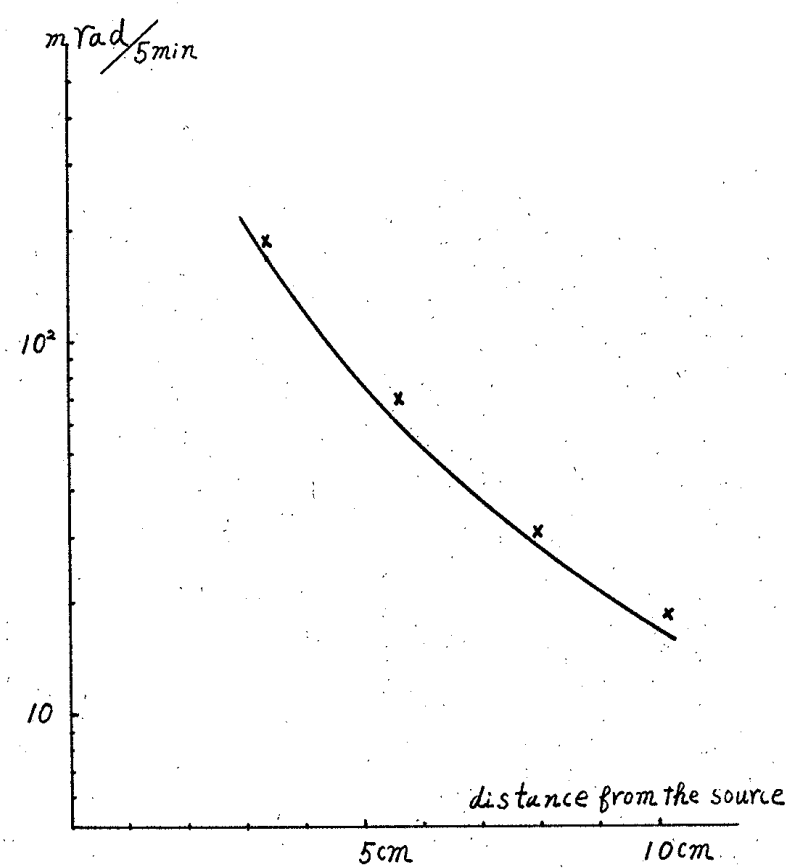

Fig. 2 Exposure rate ( $\mathrm{mrad} / 5 \mathrm{~min}$ ) in water along transverse axis line derived from $3 \mathrm{mCi}$ Radium source.

The lines represent the calculated values using equation 6 and dots the experimental values.

源からの距離をかえた場合の吸収線量を(6)式を用いて求 めた值と実測值との比較をしたものである：測定は極光 TLD 1200，MSO 素子を使用し，素子はそれぞれラジウ ム針より $3 \mathrm{~cm}, 5 \mathrm{~cm}, 7 \mathrm{~cm}, 9 \mathrm{~cm}$ の距離のアクリル板に 埋め込み Mix Dp.ファントムでサンドイッチし 5 分間, くり返し 3 回測定しその平均值を求めた，また線源から の距離はアクリル樹脂の水に対する密度補正をおこなつ
た、計算値より求めた減弱曲線乙測定值を比較するとそ の傾きについてはよく一致している。

\section{3 線 量 率}

Fig. 3 はそれぞれ active length $1 \mathrm{~cm}, 2 \mathrm{~cm}, 3 \mathrm{~cm}$ で ${ }^{226} \mathrm{Ra}, 0.5 \mathrm{mmPt}$ フ.ィル多; ${ }^{60} \mathrm{Co},{ }^{137} \mathrm{Cs} 0.5 \mathrm{~mm}$ ステンレ スフィルタについて，線源からの距離に対する吸収線量 を(6)式を用りて求めたものである.

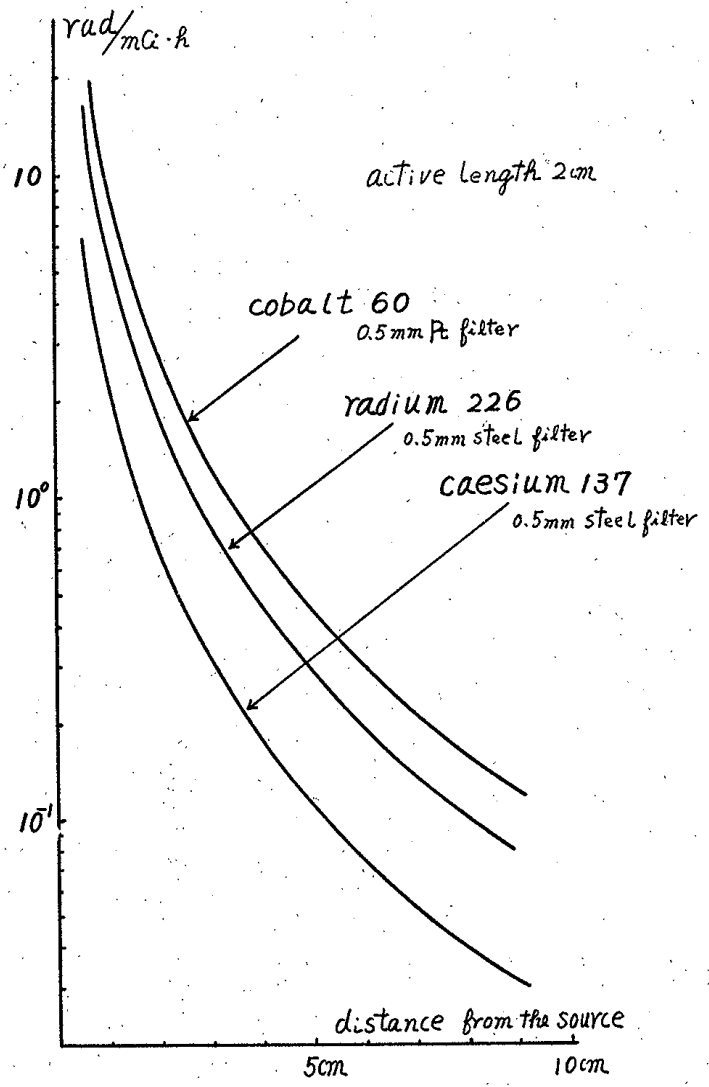

Fig. 3-1 

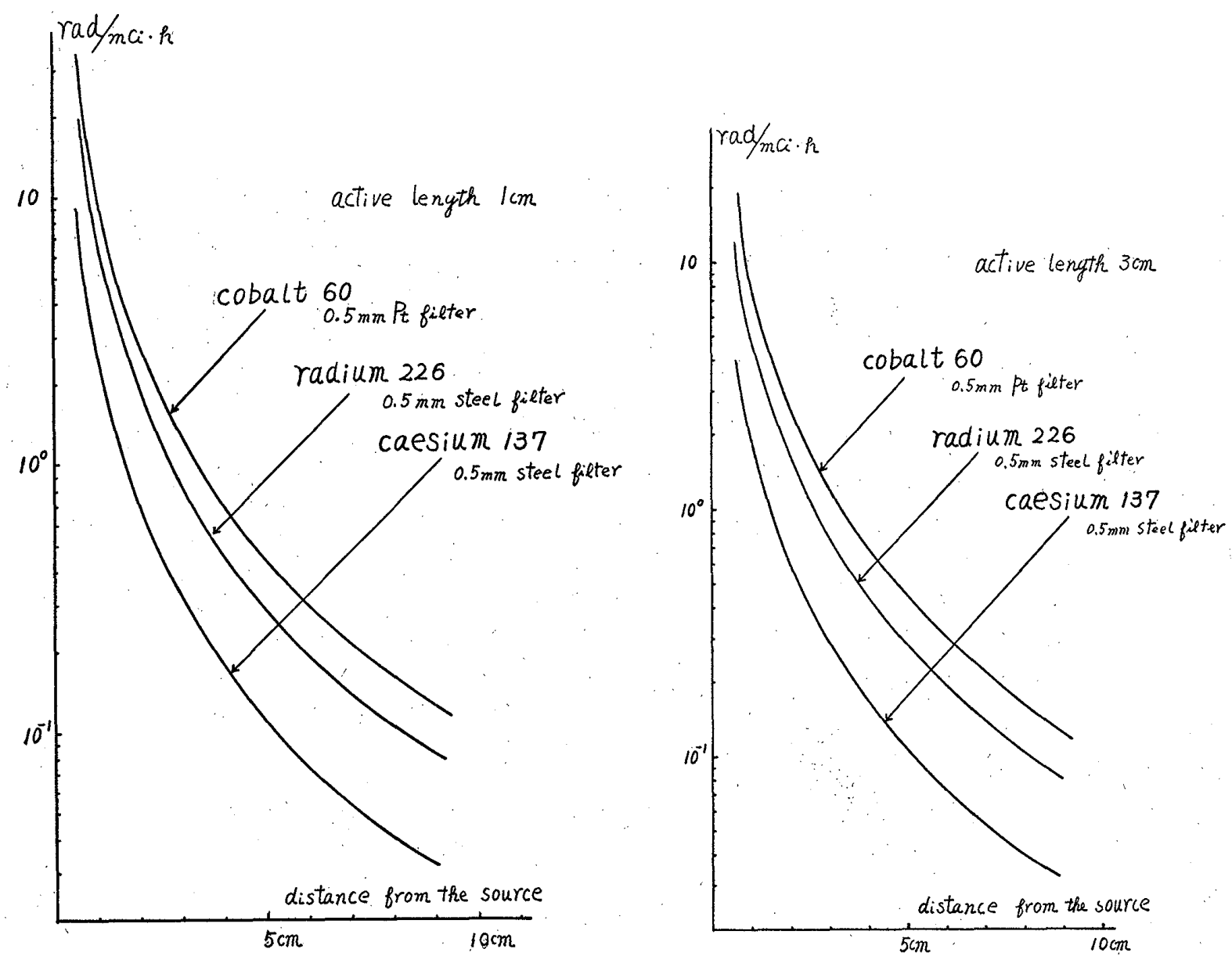

Fig. 3-2 Calculated dose rate ( $\mathrm{rad} / \mathrm{mCi}$.hour) in water along transverse axis line derived from the various line source.

\section{4 空中線量との比較}

Fig. 4 はそれぞれの線源办らの距離における，水中で の吸収線量と空気中での ${ }^{226} \mathrm{Ra}$ 線源による線量との比を 計算により求めたあのである，つまりラジウム当量とし て空気中での線量值をそのまま治療に使用すると ${ }^{137} \mathrm{Cs}$ 線源の場合， $5 \mathrm{~cm}$ の距離で約 $8 \%, 10 \mathrm{~cm}$ の距離で約 18 \%ぐらいの詥差を生じた.

\section{5 線量分布の比較}

Fig. 5 は ${ }^{137} \mathrm{Cs}$ ラジウム当量 $20 \mathrm{mg}$ の線量分布を(6)式 を用いて求め, Klevenhagen "がシリコン半導体検出器 および小さな電離箱線量計を用いて求为た線量分布と比 較したものである。

\section{4. を と}

密封小線源を使用して治療を行なう場合，治療用コン ピニータがある施設は别としてむ，そうでない施設にお いては水中での線量および線量分布を計算することは大 変手数のかかることであるが，前述(6)式を用いれば電卓
程度で比較的簡単にしかむ ${ }^{226} \mathrm{Ra}$ 以外の線源についてす その目的を達するてとが出来る，ただし，ててでは小線 源の軸方向における自己吸收，端部の形状による分布の 変形, ラジウム線源であれば 0 によって実効ェネルギー が変化する (J. Young 他 $\left.{ }^{4}\right)$ 等を考慮していないので， さらに精度を必要とする場合は，乙れ等の補正について あ検討していく必要があろう。

\section{文}

献

1) 内山幸男, 高木一広, 植田俊男: 小型計算機术 ラジウム線源の線量分布計算，日放技術誌，32. 368-374, (1976).

2) H. F. Batho and J. Young: Tissue absorption correction for linear radium sources. Brit. J. Radiol., 37, 689-692, (1964).

3) Horsler: Caesium 137 sources for use in intracavitary and interstitial radiotherapy. Brit. J. Radiol., 37, 385-390, (1964). 


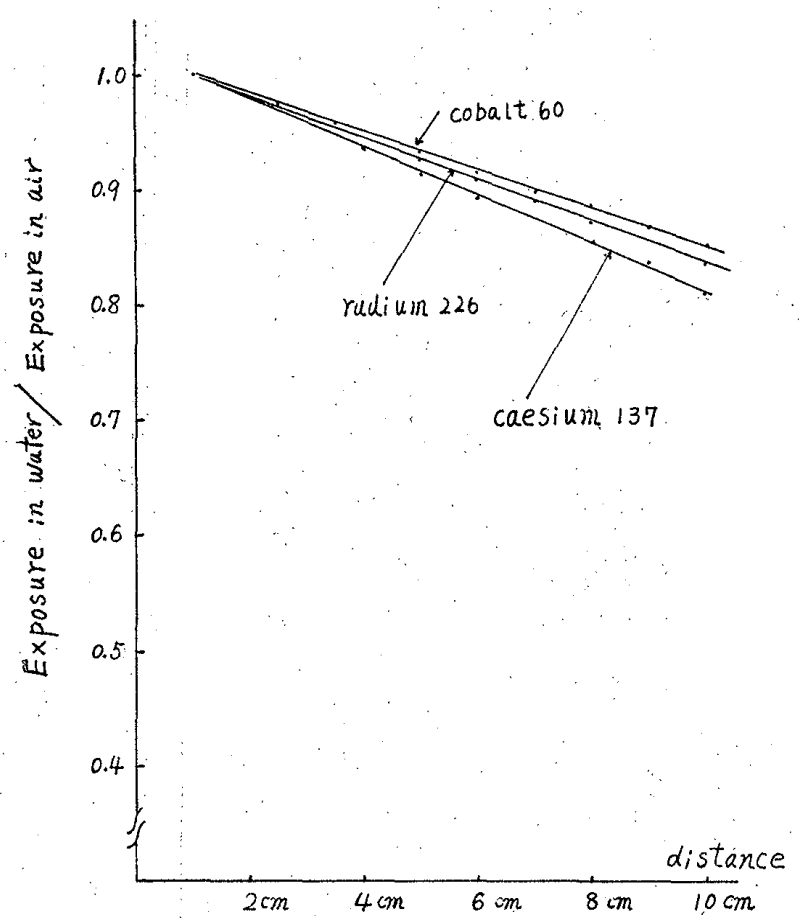

Fig. 4 The ratio between the exposure in water for equivalent radium source/ the exposure in air for radium source as. a function of distance from the linear source.

4) J. Young and H. F. Batho: Dose table for linear radium sources calculated by an electronic computer. Brit. J. Radiol., 37, 433, 38-44, (1964).

5) Johns: The physics of Radiology.

6) K. I. Ponnunni Kartha, et al: An experimental determination of the absorption and buildup factor in water for radium, cobalt 60 , and ceasium 137 gamma rays. Am. J. Rentgenol., 96, 66-69, (1966).

7) Klevenhagen: An experimental study of the dose

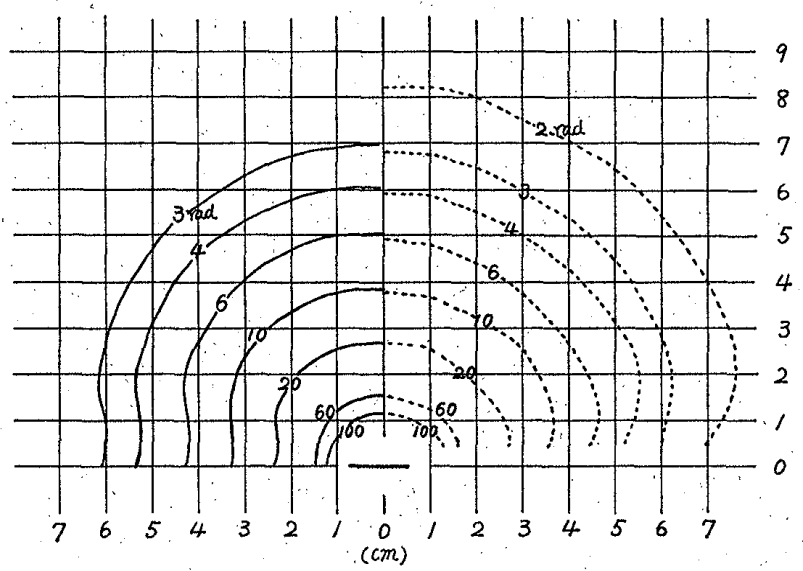

Fig. 5 Isodose distribution in $\mathrm{rad} /$ hour from a linear ${ }^{137} \mathrm{Cs}$ source containing 20 $\mathrm{mg}$ radium equivalent. Left-hand side, solid line graph is obtained by S. C. Klevenhagen. Right-hand side, dotted line graph showing the calculated dose distribution using equation 6.

distribution in water around ${ }^{137} \mathrm{Cs}$ tubes used in brachytherapy. Brit. J. Radiol., 46, 1073-1082, (1973).

8) Kaven, E. Breitman: Dose rate tables for clinical ${ }^{137} \mathrm{Cs}$ sources sheathed in platinum. Brit. J. Radiol., 47, 657-664, (1974).

9）尾内能夫，他：ラジウム治療における線量分布の計 算，日医放誌，28，1629-1635，(1969).

10）田崎瑛生，他：セシウム管の線量分布.

11) W. J. Meredith, et al.: The attenuation and scattering in a phantom of gammaray from some radionuclides used in mould and interstitial gammaray therapy. 